\title{
Development of Activated Carbon from Agricultural Waste: Sapota Peels
}

\author{
P. H. Patil*, V. R. Parate*, J. J. Jankar***, A. S. Deshpande*** and B. N. Annapurve**** \\ *Department of Food Technology, University Institute of Chemical Technology, North Maharashtra University (NMU), \\ Jalgaon, Maharashtra, India \\ **MIT College of Food Technology, MIT ADT University, Pune, India \\ ***Department of Technology, Shivaji University, Kolhapur, Maharashtra, India \\ ****SDMVMS College of Food Technology, Aurangabad, Maharashtra, India \\ $\dagger$ Corresponding author: J. J. Jankar; jankjagruti@gmail.com
}

Nat. Env. \& Poll. Tech.

Website: www.neptjournal.com

Received: 21-07-2020

Revised: $14-08-2020$

Accepted: $15-10-2020$

Key Words:

Sapota peels

Activated carbon

Lead removal

Wastewater purification

\begin{abstract}
The present study aimed to develop the activated carbon from fruit waste like sapota peel and to optimize the condition of developed activated carbon for complete removal of lead ions from the desired concentration of a lead solution. The activated carbon was prepared from sapota peel by using sulphuric acid. The physicochemical characterization of the obtained activated carbon was done for various parameters along with analysis of crystal nature (XRD) and structural morphology (SEM). The optimum conditions for adsorption were studied by altering $\mathrm{pH}(2-10)$, agitation speed (50-250 revolution per minute), temperature $\left(10-60^{\circ} \mathrm{C}\right)$, adsorbent dose $(0.02-0.14 \mathrm{~g})$ and contact time (30-240 minutes). The optimized conditions necessary for complete removal of lead ions by the prepared adsorbent were $\mathrm{pH}$ - 5.5, agitation speed -200 revolutions per minute, temperature $-60^{\circ} \mathrm{C}$, time -3 hours and adsorbent dose $-0.12 \mathrm{~g}$. This study can be further helpful in designing the process of wastewater treatment for the removal of toxic metals from water particularly lead by adsorption.
\end{abstract}

\section{INTRODUCTION}

The utilization of agricultural waste for the removal of heavy metals from the wastewater or the sewage has enticed much attention owing to its economic benefit and high removal efficiency which is attributed to different functional groups. Exposure of a person to heavy metals such as mercury and lead may cause the development of autoimmunity, in which his/her immune system attacks its own cells. This phenomenon results in joint disorders such as rheumatoid arthritis, and diseases of the kidneys, circulatory system, nervous system, and damaging of the foetal brain. Heavy metals, in higher doses, can cause irreversible brain damage (Barakat 2011). For the removal of heavy metals from the water, different techniques have been used for many years. Activated carbon method is one of them which is gaining more attention because of its advantageous nature. Pachaiyappan et al. (2012) have introduced activated carbon (AC) as a nongraphic, microcrystalline, tasteless and solid form of black carbonaceous material with a porous structure which has been considered as distinctive and multipurpose adsorbent owing to its extended surface area, microporous structure, high adsorption capacity, and a high degree of surface reactivity. Being a versatile material, activated carbon is exploited for the purification of water by removing the perilous particles in water and exhaust gases used for the wastewater treatment as well. It is not only used for gas and water purification but also for sewage treatments and many other applications (Rajamani et al. 2018). AC can be acquired from the agricultural waste such as fruit waste and play an advantageous role by being effective, low-cost replacement for non-renewable coal-based granular activated carbons (GACs) provided that they have similar or better adsorption efficiency (Martin et al. 2003). Agricultural by-products available in large amount makes them a good source of raw material for activated carbon production (Malik et al. 2007). Different types of fruit wastes have been used for the production of activated carbon such as orange peels (Xie et al. 2014), watermelon peels (Gin et al. 2014), banana peels (Chafidz et al. 2018). The present investigation was focused on the production of activated carbon from sapota peels.

\section{MATERIALS AND METHODS}

Squander sapota peels have been used for the study. The Sapota peels were procured from the local fruit market, cleaned by washing, dried in a hot air oven at a temperature around $55^{\circ} \mathrm{C}$ and ground to powder form by using a grinder. The obtained powder was subjected to further analysis. 


\section{Analysis of Raw Material}

Sapota peels were subjected for the analysis to determine various physicochemical characteristics by using standards delineated in Table 1.

\section{Preparation of Metal Adsorbent}

Activated carbon was prepared from the sapota peels by slightly modifying the method described by Demirbas et al. (2004). Peels were first dried and ground and the resulting powder was then activated by using sulphuric acid as shown in Fig. 1.

\section{Characterization of the Prepared Adsorbent}

The adsorbent was studied for different physicochemical characteristics such as bulk density and ash content as per procedures stipulated by CEFIC (European Chemical Industry Council). Bulk density was determined with the help of bulk density apparatus (DBK 5028-7). Absorbent was also analysed for the moisture content and $\mathrm{pH}$ by Bureau of Indian Standards method IS 877, (1989). Absorbent was analysed for its calorific value, which was determined by using Digital Bomb Calorimeter (Rajdhani Scientific, Model: RSB 6). The adsorbent was also tested for electrical conductivity by using conductivity meter of Systronic (Model 304) based

Table 1: Physiochemical characteristics of sapota peels. on IS 14767, (2000) method. The yield of adsorbent was calculated by using the following equation (1):

Yield $\%=\frac{\text { Weight of dried material before treatment }}{\text { Weight of dried material after treatment }} \times 100 \ldots$

\section{Study of Adsorbents in Removing Lead Ions Adsorption}

Amount of carbon and structure of its lattice was determined by using X-ray diffraction determined by using XRD of BRUKER (Germany), Model: D8 ADVANCE with a scintillation detector. Morphological characteristics of sapota peel and adsorbent prepared from it were determined by using Scanning Electron Microscope (SEM) of HITACHI (Model: S-4800, TypeII) coupled with Energy Dispersive X-ray Spectroscopy (EDS) of BRUKER.

\section{Optimization of Adsorption Condition}

The effect of $\mathrm{pH}$, agitation speed, temperature and adsorbent dose on adsorption capacity of prepared adsorbent from sapota peels was observed by keeping the other variables of adsorption such as the initial concentration of the lead solution $(50 \mathrm{ppm})$, volume of lead solution $(50 \mathrm{~mL})$, particle size of adsorbent $(0.15-0.25 \mathrm{~mm})$ and contact time $(4 \mathrm{~h})$ constant. The effect of $\mathrm{pH}$ was studied by adjusting the $\mathrm{pH}$ of solutions at 2, 3, 4, 5, 6, 7, 8, 9, 10 using 0.1-0.5 M solution of $\mathrm{NaOH}$

\begin{tabular}{|llll|}
\hline Sr. No. & Parameters & Equipment/Instruments & Methods \\
\hline 1 & Moisture & Electric hot air oven; & IS 996:1999 \\
& & Weighing balance & IS 996:1999 \\
3 & Fat & Soxhlet apparatus & IS 996:1999 \\
4 & Protein & Muffle furnace & Kjeldahl method (Ranganna) \\
5 & Crude Fibre & Pelican KES 04 LVA & IS 4706, Part-2 (1978) \\
7 & Lignocellulose content & Pelican KES 04 LVA & Van Soest \& Wine (1970)
\end{tabular}

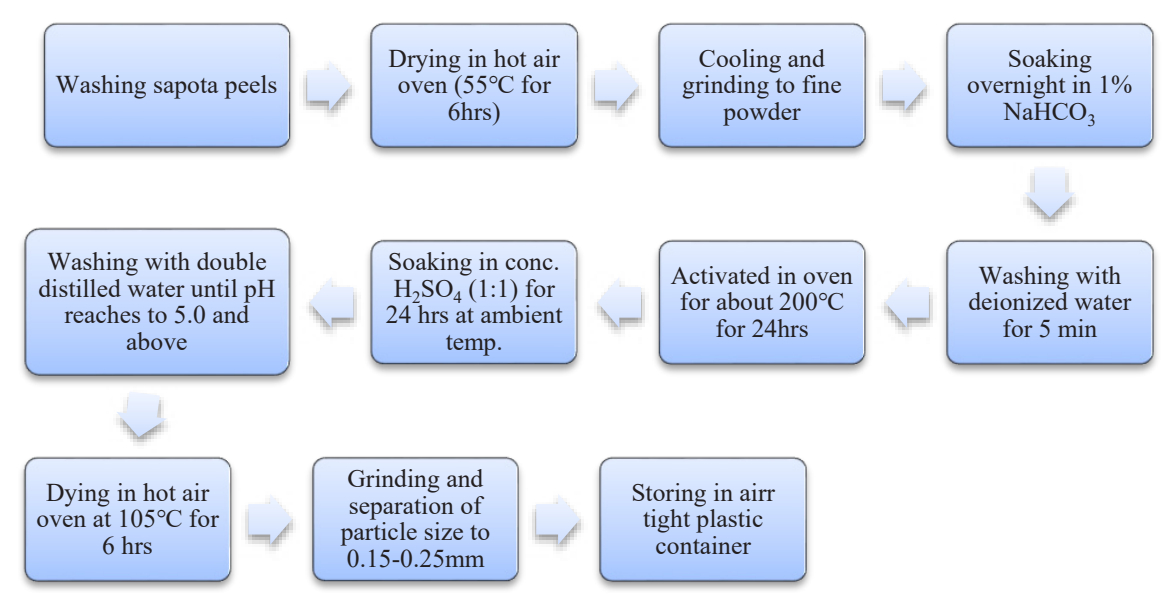

Fig. 1: Method of preparation of metal adsorbent from sapota peels. 
or $\mathrm{HCl}$. The $\mathrm{pH}$-adjusted solutions were stirred at $150 \mathrm{rpm}$ at $30^{\circ} \mathrm{C}$ with $0.5 \mathrm{~g}$ adsorbent. The obtained optimum $\mathrm{pH}$ was then maintained in all the further study of adsorption. The effect of agitation on adsorption was examined by shaking the suspension of a lead solution containing $0.5 \mathrm{~g}$ of adsorbent at various speed $(50,100,150,200$ and $250 \mathrm{rpm})$ in an incubation temperature of $30^{\circ} \mathrm{C}$. The temperature effect on lead removal was observed by maintaining the temperature at $10,20,30,40,50$ and $60^{\circ} \mathrm{C}$ keeping $\mathrm{pH}$ and agitation speed at an optimized level and adsorbent dose constant, i.e. at 0.5 $\mathrm{g}$. The effect of adsorbent dose was studied by shaking lead solution with a various dose of adsorbent $(0.1,0.25,0.5$, $0.75,1.0,1.5,2.0$ and $2.25 \mathrm{~g}$ ) keeping $\mathrm{pH}$, agitation speed and temperature at optimum condition. \% Removal was calculated by using the formula given below in equation (2).

$$
\% \text { Removal }=\frac{\mathrm{Ci}-\mathrm{Ce}}{\mathrm{Ci}} \times 100
$$

Where,

$\mathrm{C}_{\mathrm{i}}$ is the initial concentration of metal ions and

$\mathrm{C}_{\mathrm{e}}$ is the final concentration of metal ions in milligrams per litre.

The adsorption capacity was determined by using the following formula (3)

$$
\mathrm{qe}=\frac{\mathrm{V}(\mathrm{Ci}-\mathrm{Ce})}{\mathrm{W}}
$$

Where,

$\mathrm{Ci}$ is the initial concentration of lead ions in ppm.

$\mathrm{Ce}$ is the final concentration of lead ions in ppm.

$\mathrm{V}$ is the volume of solution in litre.

$\mathrm{W}$ is the weight of adsorbent in grams taken.

\section{RESULTS AND DISCUSSION}

Table 2 is showing the analysis results of sapota peel, which is a basic raw material, used in the current study.

Table 2: Results of dry raw material analysis.

\begin{tabular}{|ll|}
\hline Parameter & Result \\
\hline Moisture \% & $16.16 \pm 0.08$ \\
Fat \% & $5.19 \pm 0.12$ \\
Total ash \% & $2.13 \pm 0.16$ \\
Protein \% & $5.13 \pm 0.06$ \\
Crude fibre \% & $68.02 \pm 0.33$ \\
Cellulose \% & $39.56 \pm 0.01$ \\
Lignin \% & $14.07 \pm 0.31$ \\
\hline
\end{tabular}

All the values are means of triplicate determinations \pm standard deviation (SD).
The chemical composition of the peels was found to contain 16.16 per cent (\%) moisture, $2.13 \%$ ash, $5.19 \%$ fat, $5.13 \%$ protein, $68.02 \%$ crude fibre, $39.56 \%$ cellulose and $14 \%$ lignin. As raw material found to contain a good amount of crude fibre, lignin, and cellulose content, it was considered for preparation of adsorbent in present work.

\section{Characterization of Adsorbent}

Physicochemical characteristics of prepared adsorbent (activated carbon) were analysed and results of the raw material analysis are represented in Table 2 . The yield of carbon was found $68.02 \%$, bulk density was $0.424 \mathrm{~g} / \mathrm{cm}^{3}$ while specific conductance was $197.25 \mathrm{~ms} / \mathrm{M}$. The calorific value of prepared adsorbent carbon was $7557.23 \mathrm{Cal} / \mathrm{g}$. Moisture content and ash content was $2.77 \%$ and $2.51 \%$ respectively. Fixed carbon content also showed good results of $71.23 \%$ (Table 3 ).

\section{Crystal Nature Analysis}

Crystal nature of adsorbent was analysed by XRD method. Fig. 2 showing XRD peak obtained for developed adsorbent, verifies that the produced material was carbon. The XRD result also confirmed that the obtained adsorbent was a mixture of $69.3 \%$ amorphous and $30.7 \%$ hexagonal-shaped crystalline crystals.

The SEM photographs of raw sapota peel and activated carbon prepared from sapota peel are shown in Figs. 3(a) and 3(b). It shows that the SEM photographs of raw sapota peel have no pores or very little caves, whereas the SEM photograph of developed carbon shows caves and pores type opening.

\section{Optimization of Adsorption Study}

pH optimization: Fig. 4 represents the effect of $\mathrm{pH}$ on adsorption. The solution $\mathrm{pH}$ is an important parameter that controls the adsorption process. The $\mathrm{pH}$ value affects the surface charge of the adsorbent, the degree of ionization and

Table 3: Physiochemical characteristics of the adsorbent.

\begin{tabular}{|ll|}
\hline Parameters & Results \\
\hline Yield $(\%)$ & 68.02 \\
Bulk Density $\left(\mathrm{g} / \mathrm{cm}^{3}\right)$ & 0.424 \\
Ash $(\%)$ & $2.51 \pm 0.11$ \\
Moisture (\%) & $2.77 \pm 0.06$ \\
$\mathrm{pH}$ & $6.03 \pm 0.02$ \\
Conductivity $(\mathrm{mS} / \mathrm{m})$ & 197.25 \\
Calorific value $(\mathrm{Cal} / \mathrm{g})$ & $7557.23 \pm 0.02$ \\
Fixed carbon content $(\%)$ & $71.23 \pm 0.09$ \\
\hline
\end{tabular}

Values are mean $( \pm$ SEM) of 3 determinations 


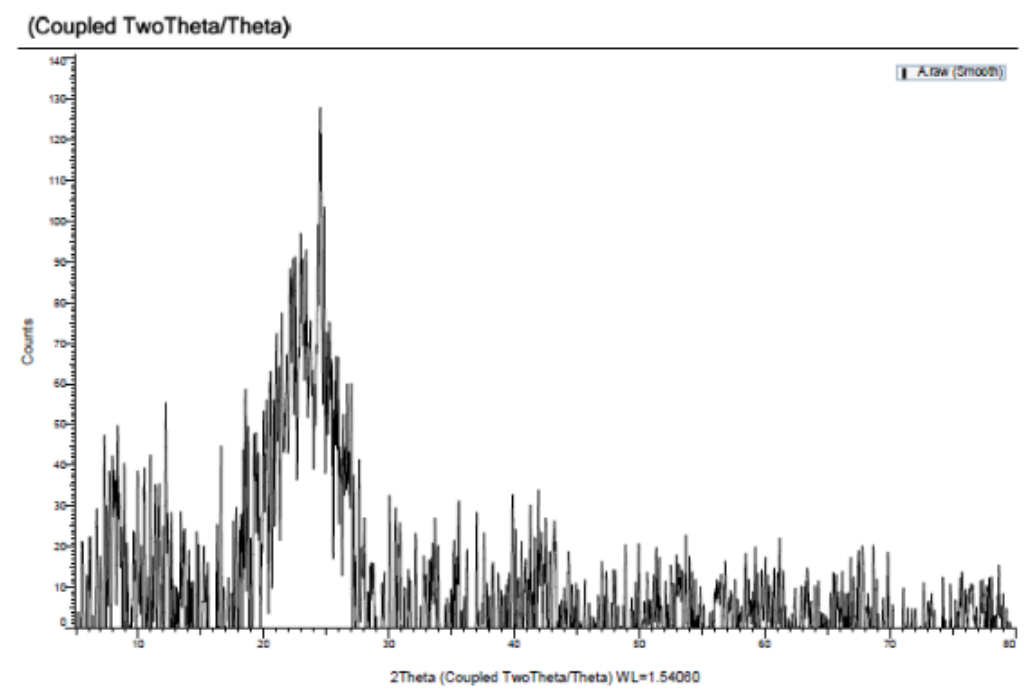

Fig. 2: X-ray diffraction (XRD) results of adsorbents.

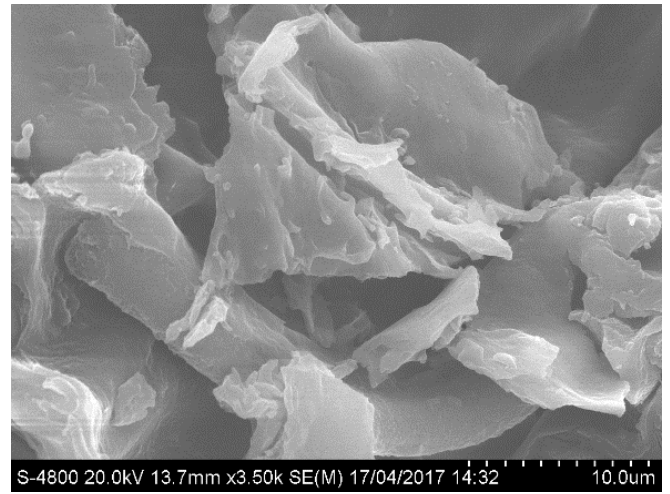

Fig. 3(a): Scanning electron microscope image of raw sapota peel.

speciation of the adsorbate during the adsorption process. The adsorption takes place by various mechanisms, and one of the import mechanisms is the electrostatic force of attraction between metal ion (possessing positive charge) and adsorbent surface (carrying negative charge). The $\mathrm{pH}$ of the aqueous solution is considered to be the most important parameter affecting the adsorption of the metal ion. From Fig. 3, it was observed as the $\mathrm{pH}$ increased the \% removal of $\mathrm{Pb}$ also increased linearly. The adsorption was very low at $\mathrm{pH} 2$ and 3 (36.96 and $49.08 \%$ removal respectively) and then increased rapidly up to $\mathrm{pH} 6(58.56 \%$ at $\mathrm{pH} 4,72.74 \%$ at $\mathrm{pH} 5,78.01 \%$ at $\mathrm{pH} 5.5,96.32$ at pH 6). At pH 6 and above the precipitation of $\mathrm{Pb}$ ion was observed due to formation of the metal complex as hydroxide. The $\%$ removal at $\mathrm{pH}$ 6 and above was high $(96.32 \%$ at $\mathrm{pH} 6$ and $97.16 \%$ at $\mathrm{pH}$ 7) because of both the combined effect of precipitation as well as of adsorption mechanism (Awwad \& Salem 2012) Therefore to support the removal of $\mathrm{Pb}$ ion only by adsorption

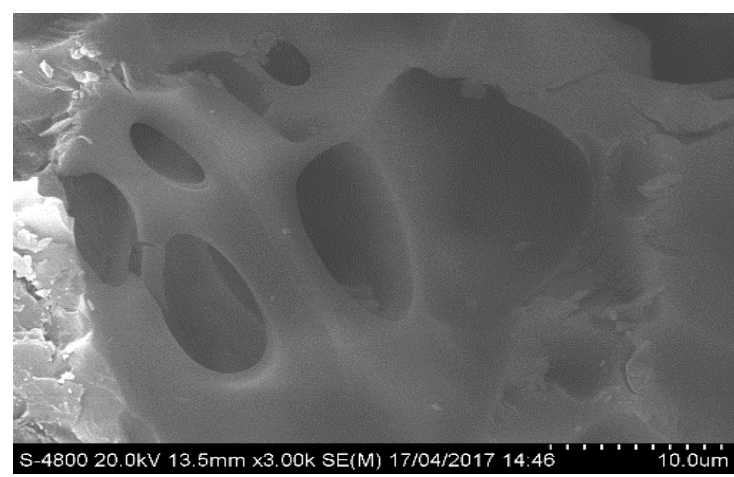

Fig. 3(b): Scanning electron microscope image of adsorbent after treatment.

and not by precipitation, the optimum $\mathrm{pH}$ for the adsorption was fixed at 5.5.

Agitation speed optimization: The effect of agitation speed on $\mathrm{Pb}$ adsorption is shown in Fig. 5. It was observed that \% removal of $\mathrm{Pb}$ increased progressively as the agitation speed increased from 50 to $200 \mathrm{rpm}$. However, the adsorption was

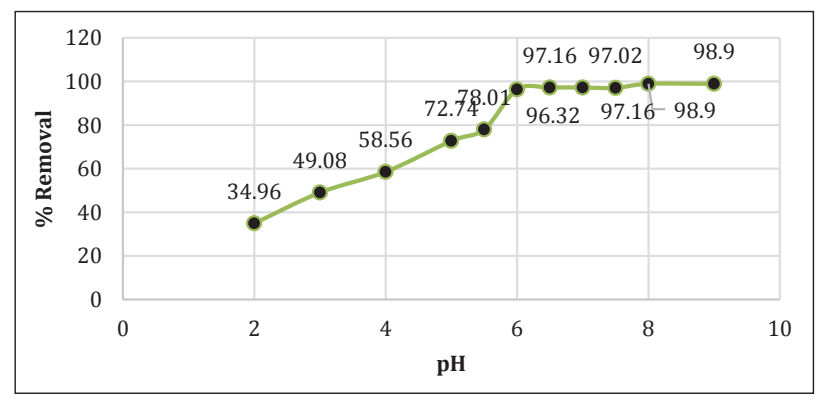

Fig. 4: Effect of $\mathrm{pH}$ on lead ions removal. 


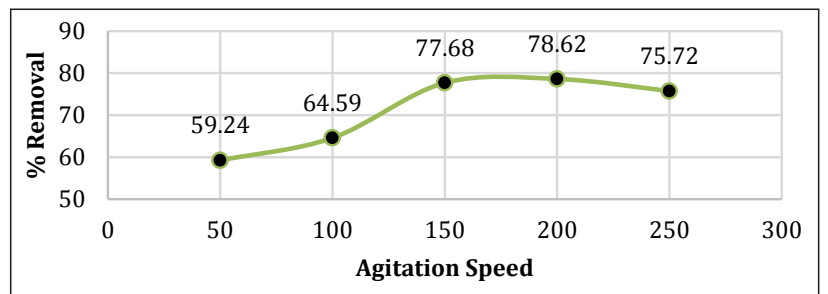

Fig. 5: Effect of agitation speed on lead ions removal.

found to be at $200 \mathrm{rpm}$ (78.62\% removal) as compared to $150 \mathrm{rpm}$ (77.68\% removal). As the shaking speed $200 \mathrm{rpm}$ was sufficient to ensure the availability of all the binding sites of the adsorbent for the uptake of maximum $\mathrm{Pb}$ ion present in solution, the optimized agitation speed was therefore selected as $200 \mathrm{rpm}$.

Temperature optimization: The effect of temperature on lead ions removal given in Fig. 6, shows the \% removal of lead ions. The removal of lead ions was observed to be increasing with an increase in temperature, i.e. from $\left(10^{\circ} \mathrm{C}\right.$ to $60^{\circ} \mathrm{C}$ ). It means that the adsorption reaction was absorbing

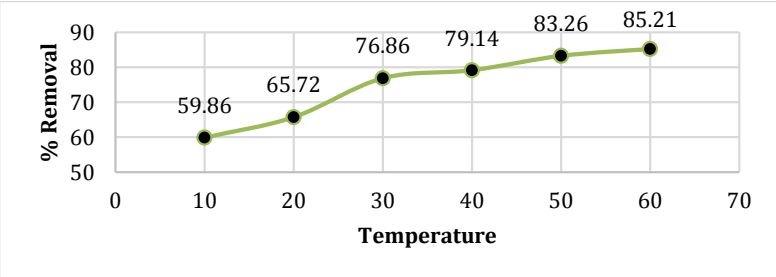

Fig. 6: Effect of temperature on lead ions removal.

heat to occur. The adsorption of lead ions was therefore considered endothermic. The $60^{\circ} \mathrm{C}$ temperature was therefore optimized for the said adsorption.

Contact time optimization: Fig. 7 shows the $\%$ removal for respective contact, i.e. from $0.5 \mathrm{hr}$ to $4 \mathrm{hr}$. The adsorption was observed to be increasing with increasing contact time. Initially, the removal of $\mathrm{Pb}$ was high due to the availability of large surface area. As the adsorption commenced, with time there was exhaustion of adsorption sites with the adsorbent. Therefore, $3 \mathrm{hr}$ time was optimized for the adsorption process.

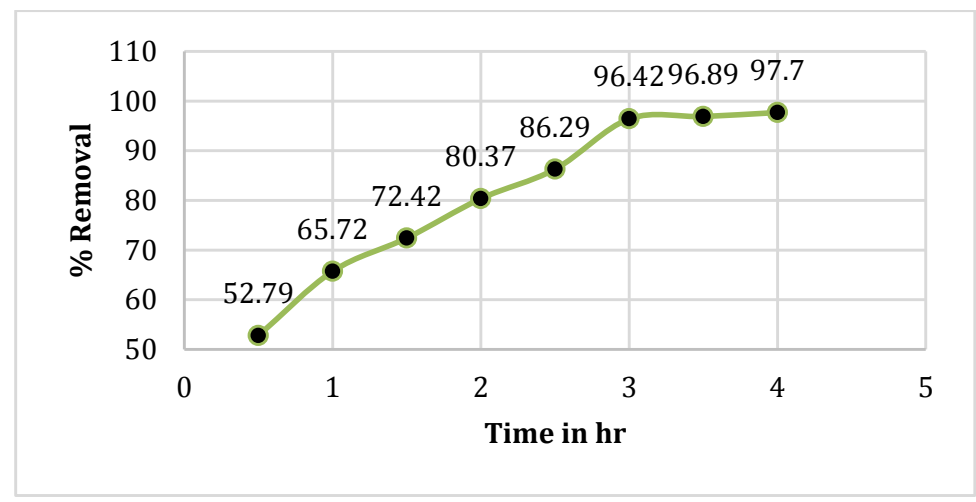

Fig. 7: Optimization of contact time for the removal of lead ions.

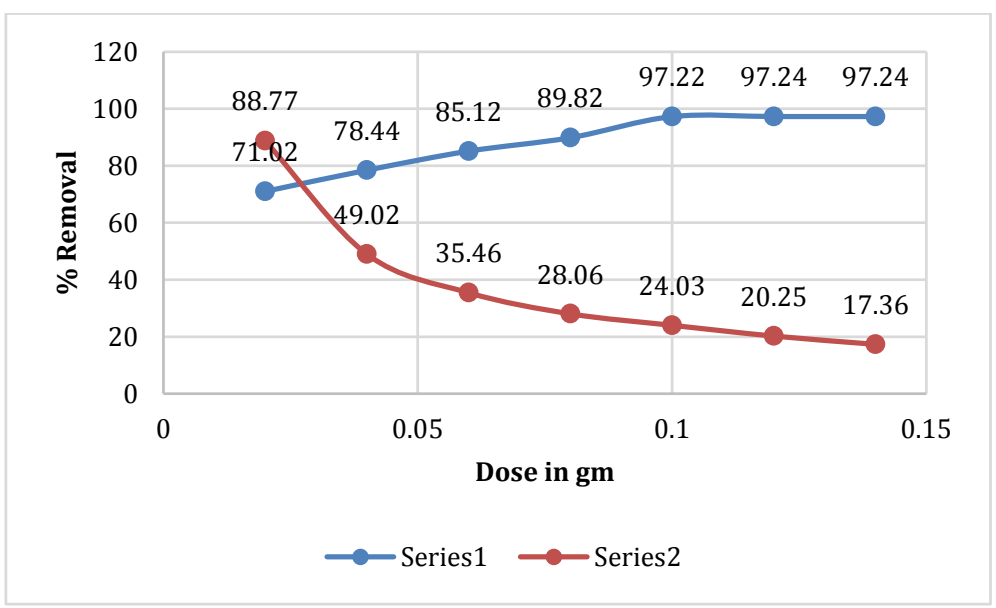

Fig. 8: Effect of dose of lead ions removal. 
Adsorbent dose optimization: The effect of adsorbent dose on $\mathrm{Pb}$ adsorption is given in Fig. 8, showing \% removal with respective adsorbent dose. \% removal of $\mathrm{Pb}$ was found to be increasing with an increase in the dose of adsorbent, whereas the adsorption capacity found to be decreasing with increasing dose of the adsorbent. The \% removal increased with increasing level of adsorbent due to the availability of large surface area which increased more numbers of adsorption sites. Therefore the adsorbent dose of $0.12 \mathrm{~g}$ is optimized for the said study of adsorption.

\section{CONCLUSION}

The effective metal adsorbent can be developed from Sapota peel by activating it with sulphuric acid. The optimized condition necessary for complete removal of lead ions by the prepared adsorbent was $\mathrm{pH}-5.5$, agitation speed - 200 revolutions per minute, temperature $-60^{\circ} \mathrm{C}$, time -3 hours and adsorbent dose $-0.12 \mathrm{~g}$. This study can be further useful in designing the process of wastewater treatment for the removal of toxic metals from water particularly lead by adsorption.

\section{REFERENCES}

Awwad, A.M. and Salem, N.M. 2012. Biosorption of copper(II) and lead(II) ions from aqueous solutions by modified loquat (Eriobotrya japonica) leaves (MLL). Journal of Chemical Engineering and Materials Science, 3(1): 7-17.

Barakat, M.A. 2011. New trends in removing heavy metal from industrial wastewater. Arabian Journal of Chemistry, 4(4): 361-377.

Chafidz, A., Astuti, W., Hartanto, D., Mutia, A. S. and Sari, P. R. 2018. Preparation of activated carbon from banana peel waste for reducing air pollutant from motorcycle muffler. MATEC Web of Conferences, 154: 01021.

Demirbas, E., Kobya, M., Senturk, E. and Ozkan T. 2004. Adsorption kinetics for the removal of chromium (VI) from aqueous solutions on the activated carbons prepared from agricultural wastes. Water SA, 30(4): 533-540.

Gin, W. A., Jimoh, A., Abdulkareem, A.S. and Giwa, A. 2014. Production of activated carbon from watermelon peel. International Journal of Scientific \& Engineering Research, 5(2): 66-71.

Hashem, S., Fayza, K., Foziah, F. and Mashael, A. 2016. Comparative study on activated carbon prepared from various fruit peels. International Journal of Innovative Research in Science, Engineering and Technology, 5(3): 2750-2759.

Malik, R., Ramteke, D.S. and Wate, S.R. 2007. Adsorption of malachite green on groundnut shell waste based powdered activated carbon, Waste Manag., 27(9): 1129-1138.

Martin, M.J., Artola, A., Balaguer, M.D. and Rigola, M. 2003. Activated carbons developed from surplus sewage sludge for the removal of dyes from dilute aqueous solutions. Activated carbons developed from surplus sewage sludge for the removal of dyes from dilute aqueous solutions. Chemical Engineering Journal, 94(3): 231-239.

Pachaiyappan, S., Susan, V., Packiyam, R. and Seshadri, S. 2012. Production and characterization of activated carbon from banana empty fruit bunch and Delonix regia fruit pod. Journal of Sustainable Energy \& Environment, 3: 125-132.

Rajamani, R., Kumar, B., Sujith, A. and Karthick, E. 2018. Activated carbon production from waste biomass. International Journal of Engineering and Technology (UAE), 7: 345-348.

Xie, Z., Guan, W., Ji, F., Song, Z. and Zhao, Y. 2014. Production of biologically activated carbon from orange peel and landfill leachate subsequent treatment technology. Journal of Chemistry, 2014, Article ID 491912. 